\title{
Effect and optimization of machine parameters of wild Chironji nut decorticator using response surface methodology
}

P.K. Nishad, S. Patel and R.K. Naik

Received : 15.01.2018; Revised : 25.02.2018; Accepted : 06.03.2018

See end of the Paper for authors' affiliation

Correspondence to :

P.K. Nishad

ICAR-Central Institute of Agricultural Engineering, Bhopal (M.P.) India

Email : praween.nishad@ gmail.com
- ABSTRACT : The kernel contains the nuts of Chironji. Traditionally, it was removed by hand hammer, small stone disc ( Jatta) or by the use of Chironji decorticator. Design experiments were conducted by using the response surface methodology (RSM) for optimizing the machine parameters of wild Chironji nut decorticator. The effect of three variables (disc speed, disc clearance and moisture content) with three levels of disc speed $(1.05,1.64$ and $2.28 \mathrm{~m} / \mathrm{s})$, three levels of disc clearance $(6,7$ and $8 \mathrm{~mm})$ and five levels of moisture treatedsample $(7.83,8.34,8.57,8.68$ and $9.04 \%$, wet basis.) was used for optimization. The maximum whole kernels percentage and minimum kernel breakage were taken as responses in order to optimize the machine parameters. The most suitable optimal results were found at disc speed $1.05 \mathrm{~m} / \mathrm{s}$, disc clearance $7 \mathrm{~mm}$ and moisture content 8.57 per cent, respectively. The capacity of decorticator, decorticating efficiency, whole kernel recovery and broken kernel recovery percentage at optimized independent parameters were $22.09 \mathrm{~kg} / \mathrm{h}$, 87.20 per cent, 16 per cent and 2.88 per cent, respectively.

- KEY WORDS : Wild Chironji nuts, Decorticator, Pre-treatment, Response surface methodology, Optimization

- HOW TO CITE THIS PAPER : Nishad, P.K., Patel, S. and Naik, R.K. (2018). Effect and optimization of machine parameters of wild Chironji nut decorticator using response surface methodology. Internat. J. Agric. Engg., 11(1) : 156-163, DOI: 10.15740/HAS/IJAE/11.1/156-163. 